\title{
Abigail Heiniger \\ Undead Blond Hair in the Victorian Imagination: The Hungarian Roots of Bram Stoker's "The Secret of the Growing Gold"
}

\begin{abstract}
The Hungarian folktale "Woman with Hair of Gold" is a part of what Nina Auerbach calls feminine mythos in Woman and the Demon. It is a story about the murder and revenge of a "very strange but beautiful woman with golden hair as fine as spun gold." This paper explores how Bram Stoker's short story "The Secret of the Growing Gold" reworks this folktale, stripping away its uniquely feminine voice, to create a story expressing British Victorian racial anxieties. The message of Teutonic superiority, which Stoker links with Hungarian folklore, is this author's most dangerous and nefarious fiction.
\end{abstract}

Since the Middle Ages, there has been a long tradition of blond hair that extends the power of women beyond the grave. ${ }^{2}$ One of the folktales that developed out of this tradition of undead blonds is a female revenge story: the blond hair of a murdered woman rises out of the grave to expose her killer. Various versions of this folktale were circulating through Victorian culture, all associated with female storytellers and a distinctly feminine medium of communication. ${ }^{3}$ During the nineteenth-century, however, male authors such as Bram Stoker appropriated these folktales. As an Irish author, Stoker would have been familiar with the ballad "The Cruel Sisters," a popular Scottish-Irish version of this traditional tale. ${ }^{4}$ However, his extensive research into Hungarian folklore would also have made him familiar with a Hungarian version, such as Clarissa Estes" "The Woman with Hair of Gold." Stoker's short story "The Secret of the Growing Gold" (1897) ${ }^{6}$ reworks this Hungarian tale. Stoker's undead blond hair negotiates the function of the hair in the traditional folktale, but he also imposes a distinctly Victorian set of ideas: the protagonist's blond hair is charged with British racial anxieties. This

\footnotetext{
1 "The Woman with Hair of Gold" is included in Clarissa Pinkola Estes' Women Who Run With Wolves (1992). This essay utilizes Estes' version because it is a short, simple telling of the basic folktale with traditional Hungarian roots (Estes 377-79).

${ }^{2}$ In On Blondes (2003), a history or blond hair in Western culture, Joanna Pitman recounts the medieval saint's legend of the Blessed Hildegard and her miraculous blond hair. Theodoric of Echternach, the final editor of Hildegard's Vita, claims that the blond relic Hildegard left behind was often used to cure sick women or protect them during childbirth (Pitman 58-59).

${ }^{3}$ In "The Power of Women's Hair in the Victorian Imagination" (1984), Elisabeth Gitter claims that a Victorian audience would have recognized the role of hair, especially in folktales, as a distinctly feminine voice (936-69).

${ }^{4}$ Robert Browning used "The Cruel Sisters" as the basis for his poem "Gold Hair" (1864). This paper utilizes the print-version of "The Cruel Sisters" published by Robert Jamieson in Popular Ballads and Songs (1806).

${ }^{5}$ Stoker's known sources for Dracula include several texts relating to Hungarian culture and folklore, including The Folktales of the Magyar (1886) according to Elizabeth Miller's "Bram Stoker's Known Sources for Dracula," which was compiled from Bram Stoker's Notes for Dracula (2008). Furthermore, in "Research in Hungarian Folk Culture" (1950), Béla Grunda claims that Hungarian folklore was popular throughout Great Britain, including Ireland and Scotland (72-74). This essay utilizes Clarissa Estes' version of "The Woman with Hair of Gold" from Women Who Run With Wolves (1992) because it is a short, simple telling of the basic folktale with traditional Hungarian roots (Estes 377-79).

${ }^{6}$ According to one source, "The Secret of the Growing Gold" was written in 1897 but published posthumously in the collection Dracula's Guest and Other Weird Stories (1914).
} 
essay explores the shift from a female revenge story with a uniquely feminine voice to a tale about racial anxieties in Victorian culture through the medium of blond hair. ${ }^{7}$

\section{Blond Hair Speaks: Weaving a Tale}

The Hungarian folktale "Woman with Hair of Gold" is a part of what Nina Auerbach in Woman and the Demon (1982) calls a feminine mythos (105). The folktale is about a "very strange but beautiful woman with golden hair as fine as spun gold" (Estes 378) who lives alone in the woods and weaves on her loom. She tries to evade the advances of a coal burner's son by offering him some of her golden hair. However, when the hair fails to bring a profit at the marketplace, the man returns and murders the nameless woman and buries her beside the river in the forest. No one takes notice of the woman's sudden disappearance, and her murderer goes free. However, the woman's golden hair continues to grow after her death. In the course of a year, her grave is covered over in curling golden reeds. Wandering shepherds cut the reeds to make flutes, but the only song the reeds will play is:

Here lies a woman with golden hair

Murdered and in her grave

Killed by the son of a coal burner

Because she wished to live. (Estes 379)

The song prompts a search for the woman's murderer and justice is done. The story ends with the statement: "... those who live in the wild woods of the world, like we ourselves do, were safe again once more" (Estes 379).

The basic narrative elements in the Hungarian folktale "The Woman with Hair of Gold" are preserved by Stoker's "The Secret of the Growing Gold": a woman is killed by her angry lover and her blond hair grows out of her grave, alerting the world to her murder and restoring justice. Thus, in both stories the undead blond hair is an active character that speaks for the woman whose voice has been violently silenced. It is significant that in both "The Woman with the Hair of Gold" and "The Secret of the Growing Gold," there is never a question that the blond hair belongs to another woman. Once the golden strands are identified as hair, there is only one woman to whom the hair could belong. In both tales, the identity of the woman is synonymous with her hair. It may be argued that the undead blond hair is transformed into the active heroine of the tale by revealing hidden transgressions.

These plot elements are not a part of the Scottish-Irish ballad "The Cruel Sisters," which would have been a convenient local version of this tale for Stoker to utilize. In the Scottish-Irish ballad, a fair haired princess is murdered by her jealous dark haired sister over a man. The drowned sister's hair is made into a harp that sings the story of her wrongful death.

The Hungarian folktale also creates a strong association between the woman's golden hair and her art of weaving. The female crafts of weaving and spinning have been associated with storytelling in the Western tradition since Ovid's tale of Philomela and Procne in the Metamorphosis, where Philomela weaves the story of her rape into a tapestry. The victimized blond weaver in the Hungarian tale is clearly a part of this ancient narrative tradition. However,

\footnotetext{
${ }^{7}$ Moreover, Stoker's distinctive and concentrated treatment of blond hair in this short story may illuminate the symbolic meaning of blonds throughout his novels. The explicit racial anxieties in this short story illuminate the more veiled racial message implicit in Stoker's other blonds, like Lucy Westenra in Dracula (1897).
} 
in Stoker's retelling of the tale, the Victorian obsession with hair replaces the female weaver and its association with a distinctly feminine storytelling tradition. Golden hair marks the grave and identifies the murderer of Stoker's blond protagonist, Margaret Delandre, but unlike Philomela's tapestry, Margaret's hair is most prominently characterized as an object of the male gaze: her hair is only described when it is being viewed by the men around her. The male gaze in Stoker's short story enforces the patriarchal system: it functions to objectify and possess the female body. It resembles the powerful Look described by Tracy Davis in "The Actress in Victorian Pornography" (1989). Davis claimed that the right to look at female bodies allowed Victorian men to define and control the social meaning of those bodies (314-15). Thus, Stoker emphasizes the gendered appropriation of this traditional folktale.

Gitter identifies a connection between women's hair, weaving, and the female storyteller throughout Victorian literature (936-39); she highlights women for whom hair functions as a "prosthetic tongue" (939). Karen Rowe expands upon Gitter's argument in her article "To Spin a Yarn: The Female Voice in Folklore and Fairy Tale" (1986); according to Rowe, weaving and spinning are "ancient paradigms for understanding the female voice in folklore and fairy tale" (297). This was especially true during the Victorian era, when images of women spinning and telling tales were used to illustrate fairy tale collections (Rowe 298).

Stoker's access to Hungarian folklore and history will be discussed later in this paper. However, it is important to note from the onset that this access was limited both materially and ideologically. As David Mandler states in the "Introduction" (2007) to The Memoirs of a Tartar (1913), British interest in Hungarian culture was primarily shaped by British travel journals and folklore collected by British or German folklorists. Thus, the British understanding of Hungary was mediate and often inauthentic (Mandler 7). Moreover, out of this artificial construction of Hungary, Stoker created his own vision of the region to support his own racial politics.

\section{Projecting Passion in "The Secret of the Growing Gold"}

"The Secret of the Growing Gold" is a story of the fatal passion of Margaret Delandre and Geoffrey Brent. Although Margaret refuses to say whether her relationship with Geoffrey is a legitimate marriage, she lives with him at Brent's Rock and travels throughout Europe with him. While they are traveling in the Alps, Geoffrey sabotages the wheels of their carriage, and it overturns, killing Margaret. ${ }^{8}$ After the crash, Geoffrey returns with a sealed box and a new Italian wife; he re-builds Brent's Rock as an Italian Villa for his foreign bride and hides the box under the hearthstone. When Mrs. Brent conceives, Margaret's undead hair breaks out from under the hearthstone and strangles the pregnant new wife and Margaret's murderous lover.

What is significant about the romantic relationships in both stories is the way in which they are projected onto the women's blond hair. In the Hungarian tale, the woman offers her hair to her sadistic suitor as a substitute for herself. The hair's lack of exchange value in the marketplace enrages the rejected lover and ends in the murder of the woman. Both the traffic and the dismissal of the blond hair is symbolic of the treatment of the woman; the coal burner's son and society fail to recognize the essential or "spiritual" (Estes 379) value of the woman and her solitary life in the woods. By contrast, Margaret does not put her hair to any utilitarian purposes

\footnotetext{
${ }^{8}$ The details of Margaret's death are not immediately apparent in the narrative. Margaret's brother Wykham inquires into the circumstances surrounding her demise, and it seems that she died in an accident (54-55). Hence the necessity of her hair to expose, and then revenge, her murder.
} 
while she is living. Her blond hair only becomes an object of desire after death when it attains the sexually-charged antagonism she and Geoffrey shared in life. ${ }^{9}$

In fact, the narrator describes the way in which violence functions as the central aspect of Margaret and Geoffrey's mutual attraction during their time together at Brent's Rock:

Neither Margaret nor Geoffrey was of a pacific temperament, and it was not long before there began to be quarrels between them.... Now and again the quarrels would assume a bitter aspect, and threats would be exchanged in uncompromising language that fairly awed the listening servants. But such quarrels generally ended where domestic altercations do, in reconciliation, and in mutual respect for the fighting qualities proportionate to their manifestation. Fighting for its own sake is found by a certain class of persons, all the world over, to be a matter of absorbing interest..." (53)

This combination of violence and desire is also apparent in Geoffrey's obsession with and repulsion to the "threads of golden hair" (60) that protrude from the shattered hearthstone at Brent's Rock. He attacks the hair, stamping it and cutting it (60-62), but he always returns to watch it; it fascinates him (60). Ultimately, this fascination destroys him as the blond hair shifts from a passive object of the male gaze to an active object that demands and transfixes the male watcher. The narrator describes how Geoffrey is forced to watch his obsession grow into the agent of his own death: "Before his horror-struck eyes the golden hair from the broken stone grew and grew; and as it increased, so his heart got colder and colder, till at last he had not power to stir, and sat with eyes full of terror watching his doom" (62). In 1888, the British Weekly ran a series of articles on "Tempted London," in which men are depicted as the victims of their own gaze; men are trapped in their own "enchantment" (278). Geoffrey Brent's demise while watching Margaret's growing hair seems to reflect this idea of victimization.

\section{Blond Roots: Victorian Familial and Racial Dimensions of Stoker's Story}

Furthermore, the sexually charged love-hate relationship between Margaret Delandre and Geoffrey Brent is a reflection of the long-standing tension and strife between the Delandres of Dander's Croft and the Brents of Brent's Rock. Like Romeo and Juliet, the lovers are representatives of their families. In this broader interpretation of their romance, Margaret's blond hair is a racial marker, which identifies her as a descendent of the ancient Anglo-Saxon yeomen who settled in Dander's Croft. Moreover, the organic, root-like behavior of Margaret's hair parallels the narrator's description of both the Delandre family and the Brent family:

The Delandre had an ancient record and were proud of it in their way as the Brents were of theirs.... They had, as the elder members used to assert, 'stuck to the land', with the result that they had taken root in it, body and soul. In fact, they, having chosen the life of vegetables, had flourished as vegetation does - blossomed and thrived in the good season and suffered in the bad. (50)

\footnotetext{
${ }^{9}$ Moreover, this interpretation of Margaret's blond hair is the only interpretation accepted by Joanna Pitman in On Blondes; Pitman states: "Blonde hair has long been familiar as a symbol of sexual temptation and corruption - both in reality and in fiction. But only the Victorians could have turned it into an instrument of death. Bram Stoker's story 'The Secret of the Growing Gold' hinges on blonde hair as the tool of revenge of a murdered woman" (146). Although Pitman represents the reigning scholarly interpretation of this short story, this is not the only possible reading of the blond hair. In fact, I would like to suggest that it is not the most significant reading. Stoker also builds Victorian racial anxieties onto this traditional folk story about the undead blond hair.
} 
The narrator states the Brent's history is "similar" (50), sending out "shoots" (51) into the world from the family home. The imagery of shoots and roots in the story eventually merges in Margaret's symbolic hair, which embodies both the ancestral heritage and the childless future of these two families. Margaret's murder and replacement with a dark, foreign-born wife is the backdrop for Victorian racial anxieties in Stoker's tale. Thus, these shoots and roots may also be emblematic of British Imperialism, which is rooted in Great Britain and sends out shoots around the world. The downfall of the Brents and Delandres in "The Secret of the Growing Gold" illustrates a turning point in the Imperialist project: this story attempts to illustrate a moment when the Nordic colonizer is infiltrated by dark haired colonized people.

In 1863, decades before "The Secret of the Growing Gold" was written, Dr. John Beddoe documents British racial anxiety in "On the Supposed Increasing Prevalence of Dark Hair in England." This article was written for the Foreign Association of the Anthropological Society of Paris and published in the Anthropological Review. According to Bell, Beddoe's analysis of hair was immensely influential, even outside scientific circles (16-18). Beddoe states:

It is the opinion of some scientific, and of many unscientific observers, that light hair is gradually becoming less common in England than it used to be; and, while some confine the bearing of this statement within the limits of their own lifetime and observation, others extend it to previous centuries, attaching great importance to terms in which our Saxon, Danish, and Norman ancestors are described as having red, yellow, or other light shades of hair. (310)

By opening his argument with an explicit link between blond hair and the Teutonic or Nordic tribes that settled in ancient Britain, Beddoe racially charges the discussion of changing hair color. From the onset, Beddoe implies that a population-wide change in hair color reflects a change in the Teutonic gene pool of Great Britain. Although the article refrains from explicit value judgments, and his argument revolves around the disinterested scientific "law of natural selection" (311), the language contains underlying anxiety. For example, Beddoe's word choice perpetually suggests that this evolutionary change in the population reflects a threat to the "more civilized" (311) British rather than biological progress or advancement.

Beddoe offers three scientific reasons for the shift in hair color. The first is an influx of dark haired immigrants (311). The scientific neutrality of Beddoe's statement is subtly undermined through his word choice. He describes recent immigration as a "constant stream" (311); the phrase carries the negative connotations of dilution, suggesting that immigration has watered down and weakened the ancient light haired British stock. Second, Beddoe suggests that the degenerating "anti-hygienic" (311) urban area selects for dark haired melanous individuals. The natural climate of the British Isles favored the "xanthous temperament" (311) of blonds, but now blonds struggle to survive in the new industrial environment. Finally, from a survey of women in his clinic, Beddoe decides that, despite popular belief in the superior beauty of blonds, British men find dark haired women more desirable wives. Thus, the brunette segment of the female population is more likely to get married and reproduce (311-12). According to his sample of 367 women, thirty-two percent of blonds remain single compared to twenty-one percent of dark haired women (312). Whether the shift is caused by changing aesthetic preferences, changing climate, or the physical influx of new people groups in Great Britain, Beddoe concludes that the British gene pool is changing. The undead blond hair in Stoker's "The Secret of the Growing Gold" is loaded with this racial anxiety. 
Although in On Blondes (2003), Joanna Pitman claims that the primary function of Margaret's hair is to take revenge on her murderer (146), it is not the injustice of Margaret's death that evokes the golden tresses to grow out of the grave. Rather, Margaret's hair responds to a racial threat, which Stoker adds to the traditional story. In Estes' Hungarian tale, the hair of the dead woman begins to grow immediately. Although it seems to take a season for the blond hair to appear beside the river in the form of curling reeds which can be made into pipes and whistles, the time lapse between the woman's murder and its discovery is governed by the natural growing season. By contrast, Margaret's hair does not begin to grow for more than a year after her death (69). Although the actual occurrences surrounding Margaret's ghostly visitation to her brother and the growth of her hair are unclear, it seems that the pregnancy of Geoffrey Brent's Italian wife is the event that initiates the appearance of her golden hair under Brents' hearthstone. ${ }^{10}$ Her blond hair is roused from the grave by the racial threat of the dark haired woman and her child, a child whose mixed heritage will dilute the ancient British stock of the Brent family.

Moreover, it is the health of the pregnant wife rather than the life of Geoffrey Brent that is initially threatened by the sprouting blond hair. When Mrs. Brent sees the blond hair breaking through the hearthstone in the Great Hall, she is stricken with a "frenzy of madness" (60) that threatens both her life and that of Geoffrey's unborn heir (60-61). However, the hair that repulses Mrs. Brent also fascinates her. Once the initial frenzy subsides, Mrs. Brent returns to the Great Hall to watch the growing gold with her husband. That return is the fatal decision that leads to their demise; the couple is wrapped in hair and petrified (61-62). It is significant that Stoker gives the nameless, pregnant Italian woman such an active role in the final confrontation with the undead blond hair. The nameless symbol of the Italian wife suggests that the hair is also symbolic and nationalistic, representing the blond British roots of Geoffrey's past rising up to punish him for sullying his Nordic heritage; the hair is not merely the manifestation of a scorned lover.

The shattering of the hearthstone by the undead blond hair also supports this racial and familial interpretation of Stoker's story. The broken hearthstone is a variation on the Hungarian folk story recorded by Estes. In Estes' story, the wilder woman is buried in the woods, and the undead tresses return as part of the natural environment. In death, as in life, the woman is in harmony with mother earth and the wild landscape. Stoker's decision to shatter the hearthstone, the familial focal point in the Great Hall, is a deliberate narrative choice loaded with meaning in the Victorian context of this tale. The action unites blond hair with the familial symbol. This connection between the hearthstone and the blond hair creates tension with the rest of Brent's Rock, which has been overhauled and rebuilt to resemble an Italian villa (54-55). In fact all the major rooms, except the Great Hall, are altered (59); through its traditional architectural décor, the central Great Hall remains a stronghold of the Nordic British past with foreign influence encroaching in upon all sides. Thus, the blond hair emanating from the hearthstone of this Nordic stronghold can easily be interpreted as the fair haired ancestral past rising to punish the living.

Stoker's portrayal of the dark haired woman as a racial threat in "The Secret of the Growing Gold" may illuminate the veiled racial implications in Stoker's other fiction. For example, in Stoker's novel Dracula (1897), Lucy Westenra is transformed from an angelic blond into a "dark-haired" (187) vampire who preys upon "a fair-haired child" (187). This passage has been interpreted various ways. However, when it is read in conjunction with Stoker's short story,

\footnotetext{
${ }^{10}$ Bram Stoker did not publish "The Secret of the Growing Gold" during his lifetime; the unresolved confusion surrounding Margaret's appearance to her brother, the disturbance at Brent's Rock, and the sprouting of blond hair under the hearthstone in the great hall may reflect the fact that Stoker's ideas were not fully developed or refined.
} 
the racist message becomes clear. The vampire invasion in the novel, which turns Lucy into a dark haired predator who destroys the blond future of Great Britain, parallels the threatening influx of dark haired immigrants, who will dilute the ancient Saxon gene pool.

Finally, in the novel Dracula, Stoker articulates his racial theory about the worn-out Teutonic heritage of Hungary. ${ }^{11}$ Thus, there are also racial implications in Stoker's decision to use a Hungarian folktale as the source for his short story. The racially dilapidated Hungary that Stoker depicts in his novel represents the future that he foresees for the rapidly deteriorating Teutonic or Nordic population in Great Britain (191-92). In Dracula, Stoker represents the Magyar of Hungary as the last in a progression of the lost warrior cultures: "the berseker Icelander, the devil-begotten Hun, the Slav, the Saxon, the Magyar" (211). The vampire has preyed upon all of these cultures, and Dracula's immigration to Great Britain suggests that this nation has also passed its era of martial power. The American cowboy in Dracula, Quincey Morris, who dies while killing the vampire king, represents the Teutonic hope of the New World (325-26). This belief remains submerged in Stoker's short story, which reworks a Hungarian folktale to illustrate the death of two ancient fair haired families in Great Britain. The Teutonic racial progression is the most deadly fictional legacy that Stoker bequeathed on posterity.

\section{The Perennial Problem of Reading Blonds}

The problem of reading blond hair is ancient; Pitman unravels the social history of blond hair in Western culture through the centuries. Although it shifts over time, blond hair generally retains a dualistic meaning. For example, gold leaf was used on icons of both Mary, the Mother of Christ, and the demon-possessed prostitute Mary Magdalene in the fifteenth-century (Pitman 54-57). Pitman sums up this dichotomy, stating:

[Blond hair] denoted ... lust and lechery, weakness and sloth, and was associated with all the sins of the world. It was also considered to be something special, powerful, sacred and almost supernatural, and in the case of women, the crowning evidence of pure beauty. (59)

This dichotomy persists throughout Medieval and Early Modern Culture. However, in the lateseventeenth- and eighteenth-century, blond hair fell out of fashion in Europe because of its strong association with prostitution. The fair beauties of Renaissance art are replaced by the "dark-haired Restoration Beauty" (Pitman 124). In the 1660s and 1670s, recipes for black hair dye began to appear in manuals and pamphlets like Ladies Guide (125). The Ladies Dictionary, published in London in 1694, informs women that blond hair is an external sign of burning sexual desire (128).

However, by the end of the eighteenth-century, blond hair resumes its magical mystique with the rise of the literary fairy tale. Pitman boldly claims that the blond heroine was a necessary component of fairy tales: "With the exception of Snow White, who has always been distinguished by her black hair, the heroines of these fairytales were always blonde... A blonde heroine was essential to a successful fairytale" (132). While potent dark haired heroines besides Snow White exist within the Western fairy tale canon, both in texts and illustrations, it is blond

\footnotetext{
${ }^{11}$ Stoker's creation of a Teutonic heritage in Hungary is either a misunderstanding of the region's history or, as Joseph Valente suggests in Dracula's Crypt (2002), a displacement of British and Irish racial tensions. Valente's argument will be discussed at length later.
} 
hair that is most often charged with symbolic meaning or magical power. This is especially true in the collection of folktales Stoker cites in his notes as one of the sources for Dracula: The Folktales of the Magyars (1864). The phrase "golden hair" appears more than twenty times in this collection, and it nearly always symbolizes a character's worth, or it is a portent of magical power. Moreover, this fairy tale magic carries into nineteenth-century Victorian culture, when the traditional preoccupation with blond hair becomes an obsession.

According to Pitman, the blond feminine dichotomy of good and evil reaches fantastic extremes in the nineteenth-century:

[Blonde hair] kindled sentimental associations with cloying fairytale heroines; but it also re-emerged as a thrilling symbol of money and of sex, and became an expression of the notorious and unquenchable Victorian fascination with these consuming twin passions. (137)

Building on blond saints and femme fatales of the past, the Victorians created a more flamboyant gold haired mythology. However, what makes the Victorian obsession with blond hair distinctive from that of other eras is that it functioned as a male fantasy rather than a female fashion (Pitman 137).

Margaret Delandre epitomizes this flamboyant and conflicted Victorian approach to blond hair. As a powerful woman, who is independent both socially and sexually, Margaret seems to represent the ultimate threat to domestic Victorian values: she cannot be a good mother. However, her vindictive blond hair makes her the embodiment of the racially pure woman who can maintain the Teutonic race. By contrast, the nameless Italian wife is a sympathetic character who embodies traditional domestic values. Thus, Stoker's racist message also becomes ambiguous: does "The Secret of the Growing Gold" advocate for Teutonic superiority or does it reveal the dangers and impossibilities of racist agendas?

In Dracula's Crypt (2002), Joseph Valente offers an alternative view of Stoker's racial politics, further demonstrating the possible ambiguity. Valente suggests that Stoker's representation of Hungary in the novel Dracula reflects his own perception of Irish and British racial politics. However, since Stoker returns to Hungarian folklore as a source of inspiration in his short story, it seems that Hungary is more than a symbol. It appears that Stoker is invested in his own idea of racial progression, which he connects with the idea of an imagined Teutonic past in Hungary.

\section{Stoker's Hungarian Sources}

In the "Foreword" to Nándor Pogány's The Hungarian Fairy Book (1913), Leo Sarkadi draws a comparison between Irish and Hungarian folklore tradition. Sarkadi states:

The Hungarian character is very much akin to that of the Irish. In fact, they are almost identical, only the Irish are more superstitious. The Hungarians also have their 'evil eye', but fewer elves play hide-and-seek in their woods, and their fairies are few in number. (viii)

Although it is apparent in Dracula that Stoker made similar connections, he also recognized and embraced the distinctive elements of Hungarian folklore. 
The corporeality of Margaret's undead existence is one of the most striking motifs from Hungarian folklore that Stoker incorporates into "The Secret of the Growing Gold." According to Emily Gerard's "Transylvanian Superstitions" (1885), a popular article that Stoker utilized in his research for Dracula, Hungarian peasants had a unique conception of death as a state that begins with a long and arduous journey to Paradise: "the road to [Paradise] is long, and is, moreover, divided off by several tolls or ferries" (128). Gerard claims that the dead were fitted with sturdy shoes, money for tolls, and even a needle and thread for patching clothes (130-31). Margaret Delandre's spirit seems to undergo a similarly taxing journey when she finally returns from death to exact her revenge upon Geoffrey Brent. When Margaret appears to her brother Wykham, she complains about the physical toll of the trek back to the vicinity of Brent's Rock (57). However, it is apparent that the undead Margaret no longer has a physical body with which to experience a physical journey; she simply materializes in her brother's home and then floats away (57). ${ }^{12}$ Only Gerard's account of Hungarian beliefs about the afterlife can account for Margaret's physical trek after death; there is no similar Irish or British paradigm.

Gerard's article was published originally in Nineteenth-Century Magazine (128-41). Her popularity later merited the attention of Blackwood's Edinburg Magazine; she wrote several articles on Transylvanian folklore for Blackwood's in 1888. While Gerard's article may not be an accurate assessment of Hungarian folk beliefs about death in the late-nineteenth-century, it shaped Stoker's perception of Hungarian folklore.

Although it is clear that "The Secret of the Growing Gold" was influenced by Hungarian folklore, his specific source for the Hungarian folktale "The Woman with Hair of Gold" is not certain because it is not included in the fairytale collections that are listed in Stoker's notes for Dracula. Pogány's The Hungarian Fairy Book is one possible source; it includes a version of this folktale entitled "The Willow-Tree" (74-84). In this tale, the undead blond hair of a murdered princess grows into the golden branches of a willow. These branches sing the princess' story and take vengeance on her killers.

The Hungarian Fairy Book is similar to The Folktales of the Magyar, which Stoker references in his notes for Dracula. It claims to be a scholarly collection of folktales meant to represent and preserve Hungarian folktales (Sarkadi vii); it is the sort of text that would have interested Stoker. Moreover, Pogány, the author of The Hungarian Fairy Book, compiled and published this collection in London. Thus, early tales such as "The Willow-Tree" may have been available prior to the book's publication in 1913.

However, it is also possible that Stoker listened to an oral version of "Women with the Hair of Gold" that was similar to Clarissa Estès' tale, which is utilized here. Dr. Estès is a practicing trauma psychologist who has recorded hundreds of tales told by women in Women Who Run with the Wolves (1992). She lists her Hungarian aunts as the source for this specific tale. Estès also speculates that "The Woman with Hair of Gold" was a "fragment of a much larger, ancient" (37-38) Hungarian narrative. Sarkadi makes similar claims about the fairy tales collected in The Hungarian Fairy Book: he claims that these fairy tales are the fragments from a rich oral tradition; an oral tradition that had been carried to England by immigrants. Gerard's "Transylvanian Superstitions" also implies that Hungarian folklore was circulating in British society (126); moreover, the popularity of her article and demands for further tales demonstrate

\footnotetext{
${ }^{12}$ Margaret also refers to herself in the past-tense during her conversation with Wykham, further indicating her undead state (57).
} 
that Hungarian folklore had developed a following. ${ }^{13}$ Moreover, Mandler's recent "Introduction" (2007) to The Memoirs of a Tartar confirms the circulation of Hungarian folklore and Hungarian narratives in Great Britain (7). Although Mandler emphasizes the way in which Ármin Vámbéry functioned as a tangible link between Hungarian and British culture, he makes it clear that Vámbéry was part of a broader cultural exchange (7-8). Similarly, there are concrete connections between Stoker and Hungarian folklore, including texts such as Poetry of the Magyars (1830) by John Bowring and The Folk-Tales of the Magyars (1886), but it is clear that he was immersed in a broader circulation of Hungarian folklore than is recorded in his journals or listed among his known sources, compiled by Elizabeth Miller.

In Stoker's "The Secret of the Growing Gold," the undead blond revenge tale from Hungarian folklore accrues Victorian ideas about femininity, blond hair, and especially about race. However, the folktale roots of Stoker's story also make it stand apart from the Victorian tradition where hair can function as a passive romantic relic. It is distinct from other Victorian stories about hair, including Charles Baudelaire's "Her Hair," Edgar Allen Poe's poem "For Annie," and Guy de Maupassant's short story "The Tresses," where the presence of the dead woman is remembered and even replaced in the imagination of her lover through the blond hair she leaves behind. Only in Stoker's story is the hair an undead, active agent that works out the desires of its mistress. Just as Rapunzel's golden rope of hair allows her lover access to her chamber in the fairy tale, blond hair allows the Victorian man imaginative access to a fairy tale woman. However, sometimes he finds the deadly witch waiting for him rather than his ideal beloved. Even in fantasy, this possibility haunts Victorian literature.

\section{Works Cited}

Auerbach, Nina. 1982. Woman and the Demon: The Life of a Victorian Myth. Cambridge: Harvard UP.

Baudelaire, Charles. 1919. "Her Hair.” Baudelaire: His Prose and Poetry. T.R. Smith, ed. New York Modern Library.

Beddoe, John. 1863. "On the Supposed Increasing Prevalence of Dark Hair in England." Anthropological Review 1.2: 310-12.

Bell, C. Jeanenne. 1998. Collector's Encyclopedia of Hairwork Jewelry: Identification and Values. Paducah: Collector Books.

Bowring, John. 1830. Poetry of the Magyars. London: R. Heward.

Browning, Robert. [1864] 2005. "Gold Hair." Robert Browning the Major Works. Oxford: Oxford UP.

Davis, Tracy. 1989. "The Actress in Victorian Pornography." Theatre Journal 41.3: 294-315. Estes, Clarissa Pinkola. 1992. "The Woman with Hair of Gold." Women Who Run with Wolves. New York: Baltine Books. 378-79.

The Folk-Tales of the Magyars. 1886. Rev. W. Henry James and Lewis L. Kropf, trans. London: Elliot Stock.

Gerard, Emily. 1885. “Transylvanian Superstitions." Nineteenth Century Magazine: 128-41.

Gitter, Elisabeth. 1984. "The Power of Women's Hair in the Victorian Imagination." PMLA: Publications of the Modern Language Association of America 99.5: 936-54.

\footnotetext{
${ }^{13}$ Gerard's article "Transylvanian Superstitions" (1885) was reprinted in Blackwood's Magazine and followed by
} other tales by Gerard about Transylvania. 
Grunda, Béla. 1950. "Research in Hungarian Folk Culture: an Ethnological and Folkloristic Survey." The Journal of American Folklore 63.247: 72-84.

Jamieson, Robert. 1806. "The Cruel Sisters." Popular Ballads and Songs. Edinburgh: A. Constable and Company.

Mandler, David. 2007. "Introduction to The Memoirs of a Tartar (1913)." Shofar: An Interdisciplinary Journal of Jewish Studies 25.3: 22-31.

Maupassant, Guy de. [1880-90] 1955. "The Tresses." The Complete short Stories of Guy de Maupassant. Artine Artinian, trans. New York: Hanover House.

Miller Elizabeth. 2008. "Bram Stoker's Known Sources for Dracula." Bram Stoker's Notes for Dracula. Philadelphia: Rosenback Museum \& Library.

Pitman, Joanna. 2003. On Blondes. New York: Bloomsbury.

Poe, Edgar Allan. [1833-49] 1992. "For Annie." The Complete Poems of Edgar Allan Poe. New York: Gramercy Books.

Pogány, Nándor. 1913. "The Willow-Tree.” The Hungarian Fairy Book. London: T.F. Unwin. 74-84.

Rossetti, Christiana. [1848-64] 1978. "The Poor Ghost." The Complete Poems of Christina Rossetti. R. W. Crump, ed. Batton Rough: Louisiana State UP.

Rowe, Karen. 1986. “To Spin a Yarn: The Female Voice in Folklore and Fairy Tale.” Fairy Tales and Society: Illusion, Allusion, and Paradigm. Philadelphia: U of Pennsylvania P.

53-74.

Sarkadi, Leo. 1913. "Foreword.” The Hungarian Fairy Book. Nándor Pogány. London: T.F. Unwin.

Stoker, Bram. [1897, 1914] 2006. “The Secret of the Growing Gold.” Dracula's Guest and Other Weird Stories. London: Penguin Books. 50-63.

“Tempted London." 10 February 1888. British Weekly. 278.

Valente, Joseph. 2002. Dracula's Crypt: Bram Stoker, Irishness, and the Question of Blood. Urbana: U Illinois P. 